Maja Pervan

University of Split

Faculty of Economics,

Business and Tourism

21000 Split, Croatia

maja.pervan@efst.hr
Marijana Ćurak

University of Split

Faculty of Economics,

Business and Tourism

21000 Split, Croatia

marijana.curak@efst.hr
JEL: G22, C67, D22

Original scientific article

https://doi.org/10.51680/ev.34.2.3

Received: November 8, 2020

Accepted for publishing: February 19, 2021

Tomislava Pavić Kramarić

University of Split

University Department

of Forensic Sciences

NonCommercial-NoDerivatives 4.0 International License

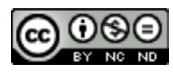

21000 Split, Croatia

tpkramaric@unist.hr

\title{
A COMPARATIVE ANALYSIS OF THE EFFICIENCY OF LIFE AND NON-LIFE SECTORS IN SELECTED CEE COUNTRIES
}

\section{Abstract}

Purpose: The aim of this paper is to analyze overall technical efficiency (OTE), pure technical efficiency (PTE) and scale efficiency (SE) of both life and non-life insurance sectors in three Central and Eastern European countries (CEE), i.e. Croatia, Hungary and Poland, in 2018.

Methodology: The efficiency of insurance sectors is estimated by applying data envelopment analysis (DEA), while a one-way analysis of variance (ANOVA) is performed to find out whether there exists any statistically significant difference between the estimated levels of the efficiency of non-life and life insurance sectors in the observed CEE countries.

Results: Out of 34 non-life Polish insurers, only two (6\%) were overall technically efficient, while the remaining 32 were inefficient. Croatia and Hungary achieved better results with three $(20 \%)$ and seven (43.7\%) efficient insurers, respectively. However, when observing the life insurance segment, half of the Croatian life insurers were efficient according to the CCR model, while six (23\%) Polish and three (23\%) Hungarian efficient insurers were recorded.

Conclusion: Research reveals that the Hungarian non-life insurers are the most efficient ones in terms of OTE, PTE and SE. They are followed by the Croatian insurers, leaving the Polish insurers behind. Regarding the life insurance sector, the domination of the Croatian insurers is recorded, while the Hungarian ones were found to be the least efficient. Moreover, inefficiency in both life and non-life sectors (except for the Hungarian life sector) is more related to scale than to managerial inefficiency. Finally, ANOVAs and Tukey post hoc tests revealed a statistically significant difference among considered groups of insurers.

Keywords: Efficiency, insurance sector, DEA, Central and Eastern European countries 


\section{Introduction}

After joining the European Union (EU) in 2004 and 2013, the insurance markets in Poland, Hungary and Croatia encountered a dynamic business environment, which is primarily reflected in a more competitive single European market. The idea of a "single European passport" enabled insurers to conduct insurance activities throughout the EU as long as they obtained a license from a regulatory body in one EU country. As suggested by Fenn et al. (2008), the assumption underlying the creation of a single market is that a greater level of competition across national frontiers will decrease costs through reduced $\mathrm{X}$-inefficiency, while mergers and acquisitions will additionally cut costs as a result of scale economies.

Despite these changes, sometimes challenged by insurance companies in these relatively new EU members, there has been no comparative research regarding the obtained efficiency levels in these countries. Specifically, most cross-country efficiency studies relating to the insurance sector focus on a group of developed European countries (e.g. Diacon et al., 2002; Fenn et al., 2008) or the USA (e.g. Cummins \& Xie, 2008; Weiss \& Choi, 2008). However, papers dealing with Central and Eastern European countries with developing insurance markets are rather scarce. In order to fill this gap, the authors performed efficiency analysis of three selected countries (Croatia, Poland and Hungary) as they share certain mutual characteristics. Precisely, Croatia, Poland and Hungary are Central and Eastern European countries (CEECs) that are relatively new EU member states. These countries have undergone a similar and rather dynamic path from being centrally managed economies with poorly developed insurance markets dominated by single state-owned insurance companies, to the transition to a market economy as well as undergoing challenging regulatory framework changes with the aim of joining the EU. Moreover, the level of the development of their insurance markets, measured by insurance density (i.e. €324, €366 and €326) and penetration (i.e. 2.6\%, 2.8\% and 2.4\%) in 2018 for Croatia, Poland and Hungary, respectively (Insurance Europe, 2020), shows considerable similarity, confirming the fact that these countries form an adequate sample for analysis.

Keeping the above in mind, the aim of this paper is to analyze (and compare) how efficient Croa- tian, Hungarian and Polish life and non-life insurance sectors were in 2018. Regarding Croatian and Hungarian insurance markets, the analysis is done on the sample of life, non-life as well as composite insurance companies whose operations are separated into life and non-life insurance sectors, while the Polish insurance market exclusively comprises companies conducting life or non-life insurance activities. This paper contributes to the existing literature due to the fact that research on cross-country overall technical efficiency, pure technical efficiency and scale efficiency in the insurance sectors of developing economies is quite scarce. Furthermore, DEA enables identification of efficient insurers within each country and benchmarking against the best of them. In addition, a comparison of the levels of efficiency in all three developing insurance markets is provided, thus enabling this paper to further add to scientific thought.

The paper is organized as follows. After the introductory section explaining the rationale for conducting such an analysis, the next section provides an overview of the existing literature. The methodology used, as well as inputs and outputs employed in the analysis, are described in the third section. The fourth section presents the obtained results, while the final section offers a conclusion.

\section{Overview of the existing literature}

The initial studies in the field of the efficiency of insurance companies were performed at the country level, and researchers later expanded their analysis by comparing the efficiency of insurance companies in different countries. A cross-country comparison started with Weiss's study (1991), while the studies that followed expanded the sample of countries by including insurers operating in OECD countries (Donni \& Fecher, 1997). In general, the findings of these studies showed significant differences in insurers' efficiency in the analyzed countries. Following deregulation of insurance markets in the EU in 1994 and industry consolidation, research focused on a comparative analysis of insurance companies operating in the EU member states. Diacon et al. (2002) studied the efficiency of 450 insurers from 15 European countries and found that insurers operating in the United Kingdom, Spain, Sweden and Denmark achieved the highest average technical efficiency score. On the other hand, insurance companies in the United Kingdom had low levels 
of scale and allocative efficiency. Fenn et al. (2008) researched the efficiency of life, non-life and composite insurers in 14 European countries covering the period from 1995 to 2001. Most insurance companies operated at increasing returns to scale. Larger insurance companies and those with a high market share were characterized by a lower level of cost efficiency. Eling and Luhnen (2010) analyzed the efficiency of 6,462 life and non-life insurance companies operating in 36 countries during the period 2002-2006. The authors analyzed the efficiency of insurance companies from different aspects (organizational form, company size, number of lines of business, different methodologies) and discovered significant differences in efficiency scores among insurance companies operating in developed and emerging countries, implying the potential for efficiency improvement in the latter. In comparison to former studies that were mainly focused on developed countries, with some exceptions encompassing both developed and undeveloped insurance markets, Biener and Eling (2011) studied the efficiency of 20 microinsurance programs in emerging countries (Africa, Asia, and Latin America) in the period from 2004 to 2008. They found substantial diversity among the programs, indicating improvement potential. Additionally, Huang and Eling (2013) analyzed the efficiency of non-life insurers in BRIC countries in the period from 2000 to 2008. They found an important effect of country-specific environmental factors on the insurers' efficiency. The most efficient non-life insurance sector was the Brazilian one, while Indian non-life insurers operated at the lowest level of efficiency. Škrinjarić (2017) analyzed the efficiency of insurance industries in 29 European countries in the period from 2004 to 2013 . The study showed that there were significant differences between the five most efficient and the five most inefficient insurance industries. Slovenia, Slovakia and Poland were among the insurance industries from CEEC that had an efficiency index equal to 1 in some years in the analyzed period. On the other hand, the Croatian insurance industry was among the five most inefficient insurance sectors in Europe. Analyzing the relationship between competition and soundness in 10 European life insurance industries, Cummins et al. (2017) found that efficiency is a channel for the influence of competition on soundness. While some of the less developed European insurance markets have been included in the sample of the studies that combine both less developed and developed markets, studies of the efficiency of insurance companies in the less developed markets have mostly been performed for a specific country. These works refer to the efficiency of insurance companies in Poland (Kozak, 2010; Kozak, 2018), Croatia (Jurčević \& Mihelja Žaja, 2013), North Macedonia (Mijackova, 2015), Serbia (Mandić et al., 2017; Lukić et al., 2018) and Slovakia (Grmanová \& Strunz, 2017). To the best of the authors' knowledge, there are only two studies that compare the efficiency of insurers operating in CEE countries. Medved and Kavčič (2012) compared the efficiency of 24 life and non-life insurers in Croatia and 15 insurance companies in Slovenia in the period 2006-2010. The results confirmed that the Slovenian insurance industry had a higher cost and technical efficiency in comparison to the Croatian insurance industry. The second study compared the efficiency of 17 insurance companies from the Czech Republic and 26 insurers from Poland for life insurance in the period 2013-2015 (Grmanová \& Pukala, 2018). The share of efficient insurers in both countries was almost equal. The average efficiency of Polish companies was higher, while the variability in their efficiency was lower in comparison to the Czech insurers. Taking into consideration that fact that little research has been conducted at the crosscountry level among Central and Eastern European countries, as well as the lack of any study of the efficiency of Hungarian insurance companies (they were only part of the sample of one cross-country analysis (Škrinjarić, 2017)), this research focuses on a comparative analysis of life and non-life insurers operating in Croatia, Hungary and Poland.

\section{Methodology and description of inputs and outputs}

Due to the nature of research, the authors applied Data Envelopment Analysis (DEA) as it utilizes a linear programming model that is based on multiple inputs and outputs and creates a single efficiency score for each decision making unit (DMU), which is in this analysis represented by an insurer. After the seminal work of Charnes et al. (1978), in which the BBC model (based on constant returns to scale) was presented, Banker et al. (1984) developed a more flexible model allowing for variable returns to scale. Since the aim of this research is to explore overall technical efficiency (OTE), pure technical efficiency (PTE) and scale efficiency (SE) of insurers operating in selected CEE countries, both of these models were used. As most insurer efficiency analy- 
ses are input-oriented (Cummins \& Weiss, 2013), we opted for input orientation. The description and reasoning for the selection of inputs and outputs used in this research is provided in what follows.

Since the sample encompasses insurance companies, it is necessary to identify services performed by insurers. In doing so, the generally accepted value-added approach is employed, categorizing insurance services into risk-pooling/bearing services, intermediation and financial services (e.g. Biener \& Eling, 2011; Cummins \& Weiss, 2013). Due to being risk-averse, policyholders are ready to pay an insurance premium in exchange for potential loss and, according to Cummins and Weiss (2013), a premium paid in addition to the expected loss is the value added by risk-pooling/-bearing. Therefore, as a proxy for risk-pooling/-bearing services we use net earned premiums as the first output in efficiency analysis, following Huang and Eling (2013). In order to proxy for an intermediation function performed by insurers, total investments are used as a second output. As stated by Cummins and Weiss (2013), insurers issue insurance policies and invest the funds collected in the form of premiums into different types of assets until the risk insured occurs or until they become due. This is also done by e.g. Biener and Eling (2011), and Huang et al. (2016). In addition to risk-pooling/-bearing services and the intermediation function performed by insurers, the financial service function is not encompassed by the analysis with a separate output due to the fact that premium income and total investments are too largely associated with the financial service function. Regarding the choice of inputs, we employ labor, business services and debt capital. Following the approach of Eling and Luhnen (2010), Biener and Eling (2012) and Biener et al. (2016), we observed labor and business services as a single input represented by operating expenses. This is often done to reduce the number of parameters or due to data unavailability. The rationale for such an approach can be found in the fact that operating expenses, i.e. the costs of insurance activity, consist of acquisition costs and administrative expenses, with commissions having a major share in acquisition costs. Specifically, acquisition costs comprise commissions, other acquisition costs and changes in deferred acquisition costs, while administrative expenses comprise depreciation of fixed assets, employee salaries and other administrative expenses. In this way, insurers' internal employees, i.e. home office labor and outsourced salesforce, are taken into account. Total technical provisions are also used as an input of an insurer and this is in accordance with Fenn et al. (2008). The total technical provisions comprise provisions for unearned premiums, provisions for bonuses and rebates, provisions for claims outstanding, mathematical provisions, special provisions, equalization provisions and other accounting technical provisions. Furthermore, we included special provisions formed by insurers pursuing life insurance business when the investment risk is borne by the policyholders. In Berger et al. (1997), this input is denoted as debt capital since it mainly contains funds borrowed from policyholders or, as stated by Huang and Eling (2013), insurance companies collect debt capital by issuing insurance policies to the insured and then "intermediate" these funds into invested assets.

Data on inputs and outputs used in this study are taken from various sources. Precisely, inputs and outputs relating to the Croatian insurance sector were retrieved from insurers' annual reports available on their web pages or from the Annual Financial Statements Registry administered by the Croatian Financial Agency (FINA) (2020). Furthermore, data on selected inputs and outputs referring to the Polish insurance market are obtained from annual reports entitled Statistics, available through the Polish Chamber of Insurance (PIU) (2020). Finally, data on operating expenses, technical provisions, earned premiums and investments registered by Hungarian insurers are retrieved from the Golden Book of Magyar Nemzeti Bank (MNB) - the Hungarian Central Bank (2020) comprising key financial data on insurers.

\section{Empirical results and discussion}

Descriptive statistics of inputs and outputs that most adequately describe the true nature of (non) life insurance business are presented in Table 1. As expected, the average amount of net earned premiums achieved in the non-life sector is higher than the one obtained in the life sector. However, this difference is not too large (approximately 7\%), suggesting that the latter should soon catch up with the more developed non-life sector. 
Table 1 Descriptive statistics of inputs and outputs for non-life and life insurers

\begin{tabular}{|l|c|c|c|c|c|}
\hline \multicolumn{7}{|l|}{} & N & Minimum & Maximum & Mean & Std. Deviation \\
\hline OPER.EXP. & 65 & 210,101 & $702,362,040$ & $44,449,625$ & $102,824,865$ \\
\hline TECH.PROV. & 65 & 908,874 & $5,265,540,310$ & $276,709,687$ & $741,345,936$ \\
\hline N.P. & 65 & 131,337 & $2,837,023,266$ & $143,683,498$ & $400,213,378$ \\
\hline INV. & 65 & $4,314,769$ & $8,773,845,523$ & $329,797,587$ & $1,128,977,606$ \\
\hline & & & Life & & Mean \\
\hline OPER.EXP. & 51 & 298,029 & $270,794,903$ & $30,471,419$ & $43,214,895$ \\
\hline TECH.PROV. & 51 & $1,529,088$ & $5,241,416,815$ & $526,625,066$ & $863,592,218$ \\
\hline N.P. & 51 & 100,587 & $1,941,534,479$ & $134,077,723$ & $277,245,590$ \\
\hline INV. & 51 & $5,727,897$ & $6,302,423,169$ & $516,077,748$ & $1,015,638,807$ \\
\hline
\end{tabular}

Note: Values of all inputs and outputs are presented in euros (exchange rates used to convert a national currency into euros were taken from EUROSTAT (2020) for 2018 as the analysis was performed for this year).

Source: Authors' calculation

The correlation analysis results are presented in Table 2. All inputs and outputs show a strong correlation as their values range from 0.897 to 0.991 . Moreover, all correlation coefficients are statistically significant at the level of 0.01 . What is most important is that all of the correlation coefficients between the inputs and the outputs are positive, in- dicating that they change in the same direction, i.e. when inputs increase, the outputs increase as well, which means that the data satisfy isotonicity (Wang et al., 2015). Hence we can proceed with the application of the DEA technique. All efficiency scores were calculated by means of Performance Improvement Management Software (PIM-DEA).

Table 2 Correlation analysis for the non-life and life insurance companies

\begin{tabular}{|c|c|c|c|c|c|c|c|c|}
\hline \multicolumn{5}{|c|}{ Non-life } & \multicolumn{4}{|c|}{ Life } \\
\hline & OPER. EXP. & TECH. PROV. & N.P. & INV. & OPER.EXP. & TECH. PROV. & N.P. & INV. \\
\hline OPER. EXP. & 1 & & & & 1 & & & \\
\hline TECH. PROV. & $.980^{\circ *}$ & 1 & & & $.897^{* * *}$ & & & \\
\hline N.P. & $.991^{* *}$ & $.990^{* s}$ & 1 & & $.912^{* *}$ & $.935^{\text {s* }}$ & 1 & \\
\hline INV. & $.951^{* *}$ & $.974^{* *}$ & $.972^{* * *}$ & 1 & $.902^{* *}$ & $.982^{* *}$ & $.938^{* * *}$ & 1 \\
\hline
\end{tabular}

** Correlation is significant at the 0.01 level (2-tailed).

Source: Authors' calculation

4.1 Efficiency analysis of the non-life insurance sector

The efficiency scores for the non-life insurance sector are presented in Table 3. According to the realized level of the overall efficiency score (OTE), as obtained by the CCR model, the lowest efficiency score was recorded in Poland (46.9\%), suggesting that, on average, insurers operating in the non-life sector can reduce their inputs by $53.1 \%$ in order to become efficient and achieve the efficien- cy frontier. It is also interesting to note that this country has the smallest number of efficient insurers. Specifically, out of 34 non-life insurers, only two $(6 \%)$ were overall technically efficient (i.e. with the recorded efficiency of $100 \%$ ), while all other remaining insurers were inefficient. The situation is better for Croatia and Hungary, where three (20\%) and seven (43.7\%) insurers were efficient. In these countries, the average overall efficiency scores amounted to $64.8 \%$ and $82.8 \%$, respectively. 


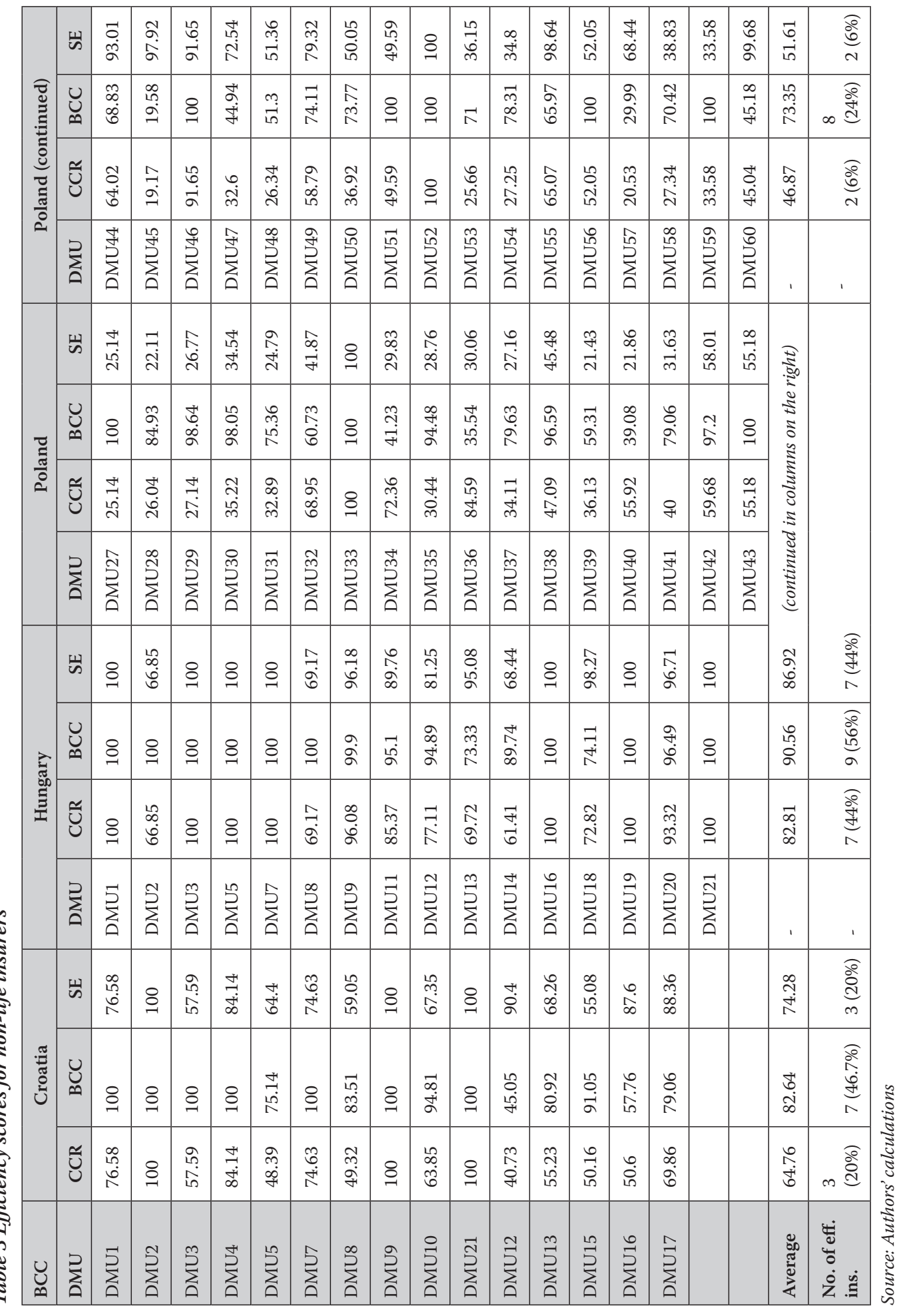


From the aspect of pure technical efficiency (PTE) obtained by the $\mathrm{BCC}$ model, it can be stated that the level of efficiency obtained for each country is higher (when compared to the OTE scores), as a larger number of non-life insurers form an efficiency frontier. Efficient insurers represent a "reference set" or benchmarks that are recognized by inefficient insurers as those with good operating practices which they need to reach. For example, reference sets for the inefficient Hungarian non-life insurer marked as DMU2 are DMU7, DMU19 and DMU21, meaning that for DMU2 to be efficient, it should use a combination of DMU7, DMU19 and DMU21 (due to space limitations, a supporting table is not presented here). A corresponding reference set is created for each inefficient insurer. In this way, every inefficient insurer can evaluate various aspects and segments of its own process of the transformation of inputs into outputs and relate it to the best operating practice in order to develop adequate plans regarding kinds of improvements that are needed and how these improvements can be made in order to become efficient (since this kind of analysis is beyond the scope of this research, we will now turn back to the elaboration and interpretation of pure technical efficiency). Given the scale size, pure technical efficiency scores for Poland, Croatia and Hungary are $73.35 \%, 82.64 \%$ and $90.56 \%$, respectively. These values point to a segment of OTE which can be attributed to the efficient transformation of inputs into outputs. Also, according to the results, the number of pure technically efficient non-life insurance companies is eight (23.5\%) for Poland, seven (46.7\%) for Croatia and nine (56.3\%) for Hungary. Again, according to the average value of pure technical efficiency and the number of efficient insurers, Hungarian insurance companies seem to be the most efficient ones, followed by Croatian and then Polish insurers. Finally, aiming to analyze whether the inefficiency of non-life insurers was due to their size or their inefficient production operation, scale efficiency (SE) was calculated by dividing the efficiency scores accomplished by the application of the CCR model by those gained by the BCC model, as proposed by Cooper et al. (2007) and later implemented by Cummins and Xie (2012), Micajkova (2015) and many others. The average values of scale efficiency for the analyzed insurers operating in CEE countries were $51.61 \%, 74.28 \%$ and $86.62 \%$ for Poland, Croatia and Hungary, respectively, suggesting that $48.39 \%, 25.72 \%$ and $13.38 \%$ inefficiency occurred because of the deviation of the current scale of production from the most productive scale size, as indicated by Ismail et al. (2011). The analysis also revealed that the overall technical inefficiency of the non-life insurers marked as DMU1, DMU3, DMU4 and DMU7 for Croatia; DMU2 and DMU8 for Hungary; and DMU27, DMU43, DMU46, DMU51, DMU56 and DMU59 for Poland, was entirely due to scale inefficiency. Likewise, the number of scale efficient insurers, i.e. insurers that recorded a scale efficiency score of $100 \%$ (meaning they were operating at the optimal size while using their particular input-output combination), is $2(6 \%), 3(20 \%)$ and 7 (44\%) for Poland, Croatia and Hungary, respectively. As for the remaining non-life insurers, SE scores were less than $100 \%$; thus they were scale inefficient. To sum up, according to the efficiency scores presented here, Hungarian non-life insurers are the most efficient ones, while insurers operating in Poland are the most inefficient ones. The efficiency of Croatian non-life insurers lies between the two. A more detailed analysis showed that although, on average, similar levels of inputs were used by the Croatian and Hungarian insurers, the latter succeeded to generate twice the amount of net earned premiums. On the other hand, technical provisions recorded in Poland were five times larger than those in the other two countries. 


\begin{tabular}{|c|c|c|c|c|c|c|c|c|c|c|c|c|c|c|c|c|}
\hline \multirow{4}{*}{$\begin{array}{l}0 \\
0 \\
0 \\
0 \\
0 \\
0\end{array}$} & 岀 & $\begin{array}{l}\hat{\sigma} \\
\text { ti. }\end{array}$ & $\stackrel{\circ}{\circ}$ & $\vec{\infty}$ & $\stackrel{\circ}{\circ}$ & $\stackrel{ }{~}$ & 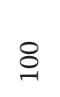 & ָָ & 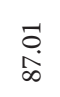 & $\begin{array}{l}\text { Ŝ. } \\
\text { مू }\end{array}$ & $\begin{array}{l}8 \\
\stackrel{0}{\circ} \\
0\end{array}$ & 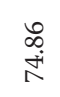 & $\begin{array}{l}\infty \\
\stackrel{\leftrightarrow}{d} \\
\alpha\end{array}$ & $\begin{array}{l}\vec{\sigma} \\
\text { ळे }\end{array}$ & $\begin{array}{c}\overrightarrow{7} \\
\text { †্ }\end{array}$ & बू \\
\hline & 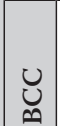 & $\begin{array}{l}\text { ㄹ. } \\
\text { \& }\end{array}$ & $\underset{\sim}{\stackrel{0}{2}}$ & 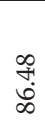 & 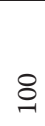 & $\stackrel{ }{\circ}$ & 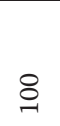 & $\begin{array}{l}\stackrel{L}{2} \\
\stackrel{2}{\Omega}\end{array}$ & $\underset{\substack{\stackrel{\infty}{i} \\
\infty}}{ }$ & $\stackrel{\infty}{\stackrel{\infty}{\wedge}}$ & $\begin{array}{l}\text { त̂ } \\
\text { जే }\end{array}$ & $\stackrel{ }{~}$ & $\begin{array}{l}\text { dें } \\
\stackrel{\circ}{\circ}\end{array}$ & $\stackrel{\square}{~}$ & 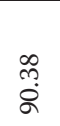 & 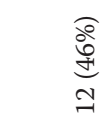 \\
\hline & Uु & $\begin{array}{l}\hat{\infty} \\
\stackrel{1}{\infty} \\
\infty\end{array}$ & $\stackrel{\circ}{\circ}$ & $\begin{array}{l}a \\
\infty \\
\infty \\
i\end{array}$ & 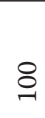 & $\stackrel{ }{~}$ & $\nsubseteq$ & $\underset{\text { 离 }}{\text { in }}$ & 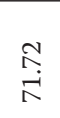 & $\begin{array}{l}\hat{\infty} \\
\stackrel{\infty}{i} \\
\hat{N}\end{array}$ & $\begin{array}{l}\text { ĥ } \\
\text { țं }\end{array}$ & 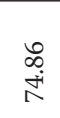 & $\stackrel{m}{\infty}$ & హె & 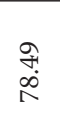 & $\begin{array}{l}\text { वें } \\
\text { तु }\end{array}$ \\
\hline & $\sum_{0}^{D}$ & 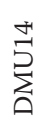 & 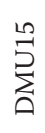 & 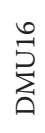 & $\stackrel{5}{\sum_{\Delta}}$ & 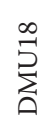 & 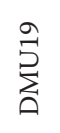 & 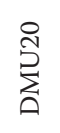 & $\stackrel{\vec{S}}{\sum_{\Delta}}$ & $\sum_{\Sigma}^{\widetilde{a}}$ & 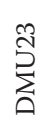 & 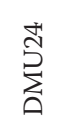 & 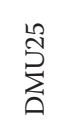 & 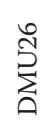 & & 1 \\
\hline \multirow{4}{*}{ 䔍 } & 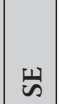 & 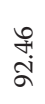 & $\begin{array}{c}\Re \\
\stackrel{h}{L} \\
\infty\end{array}$ & 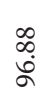 & $\begin{array}{l}\infty \\
\stackrel{\infty}{\infty} \\
\stackrel{0}{人}\end{array}$ & 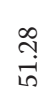 & $\stackrel{8}{\circ}$ & $\underset{\stackrel{P}{i}}{\stackrel{N}{N}}$ & $\begin{array}{l}\stackrel{0}{0} \\
\stackrel{0}{\circ}\end{array}$ & $\overrightarrow{i n}$ & $\begin{array}{l}\overrightarrow{6} \\
\stackrel{0}{\circ}\end{array}$ & $\stackrel{ }{~}$ & 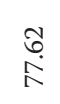 & 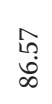 & 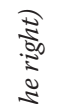 & \\
\hline & U্ল & $\begin{array}{l}\infty \\
\infty \\
\infty \\
\infty\end{array}$ & $\begin{array}{l}\text { L̊ } \\
\text { مू }\end{array}$ & $\stackrel{\circ}{\circ}$ & 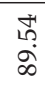 & 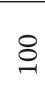 & $\stackrel{-}{\circ}$ & $\stackrel{ }{\circ}$ & 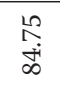 & 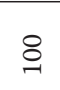 & సু & $\stackrel{\Omega}{\circ}$ & $\begin{array}{l}\vec{b} \\
\stackrel{0}{0}\end{array}$ & $\begin{array}{l}\stackrel{+}{\leftrightarrow} \\
\stackrel{+}{\sigma}\end{array}$ & $\tilde{z}$ & \\
\hline & $\widetilde{\widetilde{U}}$ & 命 & $\underset{\infty}{\mathbb{N}}$ & 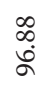 & 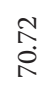 & 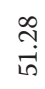 & $\stackrel{\sim}{\circ}$ & 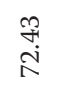 & 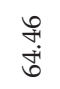 & $\overrightarrow{10}$ & $\begin{array}{l}\infty \\
\stackrel{0}{0} \\
\text { and }\end{array}$ & $\stackrel{్}{\circ}$ & $\begin{array}{l}\text { के. } \\
\text { ळ̆ }\end{array}$ & 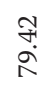 & 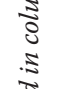 & \\
\hline & $\sum_{0}^{2}$ & $\sum_{0}^{5}$ & 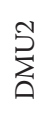 & 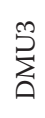 & 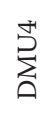 & $\sum_{n}^{n}$ & 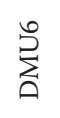 & $\sum_{\Delta}^{S}$ & 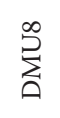 & 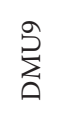 & $\stackrel{\circ}{\sum_{\Delta}}$ & $\underset{\sum^{\prime}}{\vec{B}}$ & 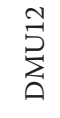 & 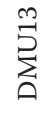 & 远 & \\
\hline \multirow{4}{*}{ 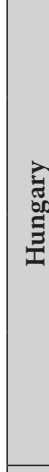 } & 岕 & $\begin{array}{l}\text { fี } \\
\stackrel{\infty}{0}\end{array}$ & $\begin{array}{l}\overrightarrow{7} \\
\stackrel{\infty}{\infty}\end{array}$ & $\underset{\sim}{\stackrel{ }{2}}$ & 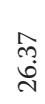 & ने & 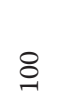 & $\stackrel{\text { में }}{\circ}$ & $\begin{array}{l}\infty \\
0 \\
0 \\
0 \\
0\end{array}$ & 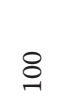 & 突 & $\begin{array}{l}\text { T. } \\
\text { : } \\
\infty \\
\infty\end{array}$ & 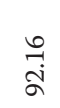 & స̂. & 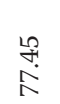 & 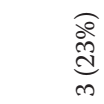 \\
\hline & U. & $\begin{array}{l}\hat{\alpha} \\
\infty \\
\infty\end{array}$ & $\hat{\circ}$ & 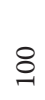 & $\stackrel{8}{ }$ & 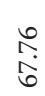 & $\stackrel{-}{~}$ & $\stackrel{ت}{0}$ & & 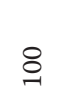 & $\stackrel{-}{2}$ & 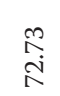 & 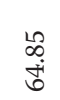 & 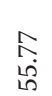 & $\frac{\infty}{10}$ & 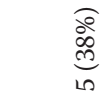 \\
\hline & $\tilde{u}$ & 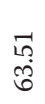 & $\underset{+\infty}{\stackrel{\infty}{0}}$ & $\stackrel{8}{\circ}$ & 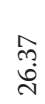 & $\stackrel{\hat{F}}{\stackrel{5}{6}}$ & 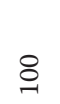 & 茴 & $\begin{array}{l}\infty \\
\propto \\
\stackrel{\infty}{\infty}\end{array}$ & $\underset{\sim}{\stackrel{1}{2}}$ & 突 & مి & $\begin{array}{l}\text { 会 } \\
\text { in }\end{array}$ & 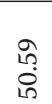 & 悉 & $\begin{array}{l}\text { बे } \\
\text { d్d } \\
\text { d. }\end{array}$ \\
\hline & $\sum_{0}^{2}$ & $\sum_{0}^{5}$ & 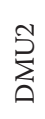 & 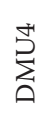 & 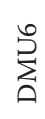 & $\sum_{\sum^{\infty}}^{\infty}$ & $\stackrel{\circ}{\sum_{\Delta}}$ & $\overrightarrow{\sum_{\Delta}}$ & 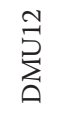 & 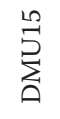 & $\stackrel{5}{\sum_{\Delta}}$ & 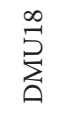 & $\stackrel{\vec{\partial}}{\sum_{1}}$ & 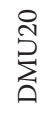 & & I \\
\hline \multirow{3}{*}{ 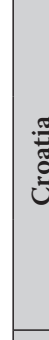 } & 岕 & \& & 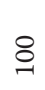 & 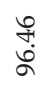 & $\stackrel{్}{\circ}$ & $\stackrel{్}{~}$ & $\begin{array}{l}\infty \\
\stackrel{\infty}{+} \\
\text { sं }\end{array}$ & 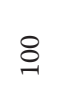 & $\stackrel{-}{~}$ & $\begin{array}{l}\hat{b} \\
\stackrel{\infty}{\infty}\end{array}$ & 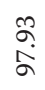 & $\begin{array}{l}\hat{\alpha} \\
\infty \\
\infty \\
\infty\end{array}$ & $\begin{array}{l}\vec{b} \\
\stackrel{\infty}{\alpha}\end{array}$ & & 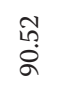 & 0 嗃 \\
\hline & U & $\stackrel{్}{\circ}$ & $\stackrel{\circ}{\circ}$ & 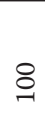 & $\stackrel{్}{.}$ & $\stackrel{-}{ }$ & $\stackrel{9}{\circ}$ & $\underset{\sim}{\stackrel{9}{2}}$ & $\stackrel{-}{~}$ & $\stackrel{\circ}{\stackrel{1}{2}}$ & 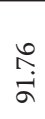 & $\underset{\sim}{\stackrel{9}{2}}$ & 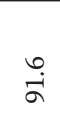 & & $\begin{array}{l}\stackrel{2}{\circ} \\
\stackrel{\leftrightarrow}{\sigma}\end{array}$ & ○ \\
\hline & ్ㅜ & 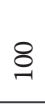 & $\underset{\sim}{\stackrel{0}{2}}$ & $\begin{array}{l}\text { ț } \\
\text { هँ }\end{array}$ & 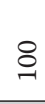 & $\stackrel{ }{\circ}$ & $\begin{array}{l}\text { के } \\
\text { षें }\end{array}$ & $\stackrel{8}{\circ}$ & $\stackrel{\odot}{\circ}$ & $\begin{array}{c}\hat{.} \\
\infty \\
\infty\end{array}$ & $\begin{array}{l}\widehat{\infty} \\
\stackrel{0}{\infty} \\
\infty\end{array}$ & $\begin{array}{l}\hat{\alpha} \\
\infty \\
\infty \\
\infty\end{array}$ & $\begin{array}{l}\overrightarrow{5} \\
\dot{8}\end{array}$ & & $\begin{array}{l}\text { त् } \\
\stackrel{\infty}{\infty}\end{array}$ & 0 宮 \\
\hline U্口 & $\sum_{n}^{2}$ & 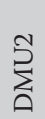 & $\sum_{n}^{m}$ & 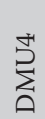 & 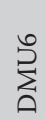 & 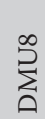 & $\sum_{\text {ț }}^{a}$ & $\sum_{\Delta}^{\infty}$ & 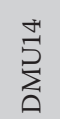 & 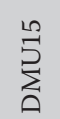 & $\sum_{\substack{L\\
}}^{0}$ & 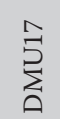 & 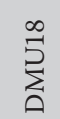 & & 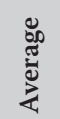 & $\begin{array}{l}\ddot{b} \dot{g} \\
\dot{0} \dot{z}\end{array}$ \\
\hline
\end{tabular}




\subsection{Efficiency analysis of the life insurance sector}

The results of the efficiency analysis performed on life insurers can be found in Table 4. It is noticeable that all efficiency scores, i.e. OTE, PTE and SE for Croatia and Poland, are much higher in the life insurance sector than in the non-life sector. The opposite is true for Hungary, for which the life-sector recorded smaller efficiency values than the non-life sector. A more detailed analysis of each country indicates that according to the number of efficient life insurance companies, Croatia is the leading country, as half of the life insurers are efficient according to the CCR model, and more than $80 \%$ of the insurers are efficient according to the BCC model. Croatia is followed by Poland with $23 \%$ and $46 \%$ of efficient insurers and then Hungary with $23 \%$ and $38 \%$ of efficient insurers, depending on whether the CCR or BCC is applied. The same order of the countries is repeated once again when the average values of overall technical efficiency, pure technical efficiency and scale efficiency are observed. Specifically, according to the average values of OTE, PTE and SE, life insurers operating in Croatia are most efficient (with efficiency scores of $89 \%, 92 \%$ and $91 \%$ ), followed by Poland (with efficiency scores of $79 \%, 90 \%$ and $84 \%$ ), while leaving Hungary behind (with efficiency scores of $62 \%, 75 \%$ and $77 \%$ ).

It is worth mentioning that the scale efficiency scores are lower than the pure technical efficiency scores in all countries in both life and non-life sectors (the only exception is the Hungarian life sector), implying that the main source of insurers inefficiency is more related to scale inefficiency than to the managerial inefficiency. This further indicates that an increase in pure technical efficiency can be realized through an increase in the scale of operation in the insurance industry (the size of insurers), as noted by Karbhari et al. (2018). Thus, in order to increase scale operation, insurers might become involved in M\&A activities. As regards the individual studies conducted earlier on the insurance industry in the analyzed three CEE countries, it can be stated that the none of the obtained efficiency scores from either of the two previous studies carried out in Croatia (Medved \& Kavčič, 2012; Jurčević \& Mihelja Žaja, 2013) can be directly compared with the efficiency scores obtained in the present research, as neither of earlier studies separately analyzed the non-life and the life insurance sector. Moreover, in both studies, the last year that was analyzed was 2010, while in this research analysis is performed for 2018. Still, we will mention that OTE and SE achieved by Medved and Kavčič (2012) ranged from 0.6 to 0.89 (for OTE) and from 0.64 to 0.93 (for SE), while the OTE and PTE scores recorded by Jurčević and Mihelja Žaja (2013) ranged from 0.74 to 0.95 (for OTE) and from 0.91 to 0.98 (for PTE), depending on the particular year that was included in the analysis. Furthermore, no studies covering OTE, PTE or SE were found for the Hungarian insurance industry, while only one piece of research has been detected for Poland (i.e. Grmanová \& Pukala, 2018), although the authors analyzed only the life sector in 2014 and used only PTE, which they found out to be 0.62 .

\subsection{One-way analysis of variance (ANOVA)}

In order to test whether there are any statistically significant differences between the obtained levels of efficiency of both non-life and life insurers operating in the analyzed CEE countries, a one-way analysis of variance (ANOVA) is performed. However, when performing ANOVA one must have in mind that while examining three groups of independent insurers, i.e. insurers operating in three different countries, ANOVA can only provide information on whether at least two groups of analyzed insurers are statistically different. Thus, in order to find out which specific group of insurers was significantly different from the others, a Tukey post hoc test is performed. Conducting ANOVA for non-life and life sectors separately, using another efficiency score each time (i.e. OTE, PTE and $\mathrm{SE}$ ) for the group of three countries (Croatia - CRO, Hungary - HU and Poland - PL) resulted in six ANOVA outputs. Abridged results are summarized in Table 5. 
Table 5 ANOVA results

\begin{tabular}{|c|c|c|c|c|c|c|c|c|}
\hline \multicolumn{5}{|c|}{ Non-life } & \multicolumn{4}{|c|}{ Life } \\
\hline \multirow{2}{*}{$\begin{array}{l}\text { Type of } \\
\text { efficiency } \\
\text { scores }\end{array}$} & \multicolumn{2}{|c|}{ ANOVA } & \multicolumn{2}{|c|}{ Post Hoc Test } & \multicolumn{2}{|c|}{ ANOVA } & \multicolumn{2}{|c|}{ Post Hoc Test } \\
\hline & $\mathbf{F}$ & Sig. & Country & Sig. & F & Sig. & Country & Sig. \\
\hline \multirow{3}{*}{ OTE } & & & CRO and $\mathrm{HU}^{*}$ & 0.030 & & & CRO and HU* & 0.000 \\
\hline & & & CRO and $\mathrm{PL}^{*}$ & 0.000 & & & $\mathrm{CRO}$ and $\mathrm{PL}^{*}$ & 0.031 \\
\hline & 30,205 & 0.000 & $\mathrm{HU}$ and $\mathrm{PL}^{*}$ & 0.000 & 10,517 & 0.000 & $\mathrm{HU}$ and $\mathrm{PL}^{*}$ & 0.025 \\
\hline \multirow{3}{*}{ PTE } & & & $\mathrm{CRO}$ and $\mathrm{HU}$ & 0.560 & & & CRO and HU* & 0.001 \\
\hline & & & CRO and PL & 0.112 & & & CRO and PL & 0.330 \\
\hline & 6,3226 & 0.003 & $\mathrm{HU}$ and $\mathrm{PL}^{*}$ & 0.003 & 8,963 & 0.000 & $\mathrm{HU}$ and $\mathrm{PL}^{*}$ & 0.005 \\
\hline \multirow{3}{*}{ SE } & & & $\mathrm{CRO}$ and $\mathrm{HU}$ & 0.198 & & & $\mathrm{CRO}$ and $\mathrm{HU}^{*}$ & 0.039 \\
\hline & & & CRO and $\mathrm{PL}^{*}$ & 0.008 & & & CRO and PL & 0.102 \\
\hline & 14,783 & 0.000 & HU and PL* & 0.000 & 3,453 & 0.040 & $\mathrm{HU}$ and PL & 0.692 \\
\hline
\end{tabular}

"The mean difference is significant at the 0.05 level.

Source: Authors' calculation

In brief, the results of all conducted ANOVAs indicated that regardless of the type of efficiency score used and the insurance sector observed (either non-life or life), there was a statistically significant difference between at least two groups of analyzed insurers. On the other hand, a Tukey post hoc test revealed a statistically significant difference among all three groups of insurers when considering overall technical efficiency (OTE). From the aspects of pure technical efficiency (PTE) and scale efficiency (SE), a difference generally occurred between Hungary and Poland in the non-life sector and Croatia and Hungary in the life sector.

\section{Concluding remarks}

The main goal of this research was to analyze overall technical efficiency, pure technical efficiency and scale efficiency of insurers operating in non-life and life insurance sectors in three CEE countries, i.e. Croatia, Hungary and Poland, in 2018. The analysis was performed with the input-oriented DEA model in which operating expenses and total technical provisions were used as inputs, while net earned premiums and total investments were used as outputs. The results of the conducted analysis revealed that, according to all efficiency scores (OTE, PTE and SE), Hungarian non-life insurers were the most efficient ones, followed by Croatian and then by Polish insurers, which were found to be the most inefficient ones. The situation is quite different when the life insurance sector is observed. Overall technical efficiency, pure technical efficiency and scale efficiency for Croatia and Poland recorded much higher values in this sector than in the nonlife sector. The exception is Hungary, for which the life sector showed efficiency values smaller than for the non-life sector. Furthermore, the efficiency scores of Hungarian life insurers were smaller than those of Croatian insurers, which were found to be the most efficient ones, and which were followed by the Polish insurance companies. In other words, the Hungarian life insurers were found to be the most inefficient ones. The order of the analyzed CEE countries remained unchanged even when it was observed from the aspect of the number of efficient life insurers. It was also revealed that in all countries and in both life and non-life sectors (except for the Hungarian life sector), the main source of insurer inefficiency appeared to be scale inefficiency rather than managerial inefficiency, suggesting the necessity of increasing the insurers' size in order to increase their efficiency. Finally, when overall technical efficiency (OTE) is observed, a Tukey post hoc test indicated a statistically significant difference among all three groups of insurers regardless of whether they were operating in the non-life or the life insurance sector. On the other hand, when pure technical efficiency (PTE) and scale efficiency (SE) are taken into account, a significant difference generally appeared between Hungary and Poland in the non-life sector and Croatia and Hungary in the life sector.

Depending on data availability, the sample of the analyzed countries could be expanded in future research. In addition, a cross-country analysis of nonlife and life insurers' productivity with the application of the Malmquist index could be performed. 


\section{REFERENCES}

1. Banker. R. D., Charnes, A. \& Cooper, W. W. (1984). Some models for estimating technical and scale inefficiencies in data envelopment analysis. Management Science, 30(9), 1078-1092. https://doi.org/10.1287/mnsc.30.9.1078

2. Berger, A. N., Cummins, J. D. \& Weiss, M. A. (1997). The coexistence of multiple distribution systems for financial services: the case of property-liability insurance. The Journal of Business, 70(4), 515-546. https://doi.org/10.1086/209730

3. Biener, C. \& Eling, M. (2011). The performance of microinsurance programs: A data envelopment analysis. Journal of Risk and Insurance, 78(1), 83-115. https://doi.org/10.1111/j.1539-6975.2010.01404.x

4. Biener, C. \& Eling, M. (2012). Organization and efficiency in the international insurance industry: A cross-frontier analysis. European Journal of Operational Research, 221(2), 454-468. https://doi.org/10.1016/j.ejor.2012.03.037

5. Biener, C., Eling, M. \& Wirfs, J. H. (2016). The determinants of efficiency and productivity in the Swiss insurance industry. European Journal of Operational Research, 248(2), 703-714. https://doi.org/10.1016/j.ejor.2015.07.055

6. Charnes, A., Cooper. W. W. \& Rhodes, E. (1978). Measuring the efficiency of decision making units. European Journal of Operational Research, 2(6), 429-444. https://doi.org/10.1016/0377-2217(78)90138-8

7. Cooper, W. W., Seiford, L. M. \& Tone, K. (2007). Data Envelopment Analysis: A Comprehensive Text with Models, Applications, References and DEA-Solver Software. Springer.

8. Croatian Financial Agency (FINA) (2020). Annual Financial Reports Registry. http://rgfi.fina.hr/JavnaObjava-web/jsp/prijavaKorisnika.jsp

9. Cummins, J. D., Rubio-Misas, M. \& Vencappa, D. (2017). Competition, efficiency and soundness in European life insurance markets. Journal of Financial Stability, 28, 66-78. https://doi.org/10.1016/j.jfs.2016.11.007

10. Cummins, J. D. \& Xie, X. (2008). Mergers and acquisitions in the US property-liability insurance industry: Productivity and efficiency effects. Journal of Banking and Finance, 32(1), 30-55. https://doi.org/10.1016/j.jbankfin.2007.09.003

11. Cummins, J. D. \& Xie, X. (2012). Efficiency, productivity, and scale economies in the U.S. propertyliability insurance industry. Journal of Productivity Analysis, 39(2), 141-164. https://doi.org/10.1007/s11123-012-0302-2

12. Cummins. J. D. \& Weiss, M. A. (2013). Analyzing firm performance in the insurance industry using frontier efficiency and productivity methods. In Dionne, G. (Ed.), Handbook of Insurance (pp. 795861). Springer. https://doi.org/10.1007/978-1-4614-0155-1_28

13. Diacon, S. R., Starkey, K. \& O’Brien, C. (2002). Size and efficiency in European Long-term Insurance Companies: An International Somparison. The Geneva Papers on Risk and Insurance - Issues and Practice, 27(3), 444-466. https://doi.org/10.1111/1468-0440.00184

14. Donni, O. \& Fecher, F. (1997). Efficiency and Productivity of the Insurance Industry in the OECD Countries. The Geneva Papers on Risk and Insurance - Issues and Practice, 22(4), 523-535. https://doi.org/10.1057/gpp.1997.37

15. Eling, M. \& Luhnen, M. (2010). Efficiency in the international insurance industry: A cross-country comparison. Journal of Banking and Finance, 34(7), 1497-1509. https://doi.org/10.1016/j.jbankfin.2009.08.026

16. Eurostat (2020). ECU/EUR exchange rates versus national currencies. https://ec.europa.eu/eurostat/databrowser/view/tec00033/default/table?lang=en

17. Fenn, P., Vencappa, D., Diacon, S., Klumpes, P. \& O’Brien, C. (2008). Market structure and the efficiency of European insurance companies: A stochastic frontier analysis. Journal of Banking and Finance, 32(1), 86-100. https://doi.org/10.1016/j.jbankfin.2007.09.005 
18. Grmanová, E. \& Pukala, R. (2018). Efficiency of insurance companies in the Czech Republic and Poland. Oeconomia Copernicana, 9(1), 71-85. https://doi.org/10.24136/oc.2018.004

19. Grmanová, E. \& Strunz, H. (2017). Efficiency of insurance companies: Application of DEA and Tobit analyses. Journal of International Studies, 10(3), 250-263. https://doi.org/10.14254/2071-8330.2017/10-3/18

20. Huang, W. \& Eling, M. (2013). An efficiency comparison of the non-life insurance industry in the BRIC countries. European Journal of Operational Research, 226(3), 577-591. https://doi.org/10.1016/j.ejor.2012.11.008

21. Insurance Europe (2020). European insurance industry database - Total Insurance. https://www.insuranceeurope.eu/insurancedata

22. Ismail, N., Alhabshi, D. S. O. \& Bacha, O. (2011). Organizational form and efficiency: the coexistence of family takaful and life insurance in Malaysia. Journal of Global Business and Economics, 3(1), 122-137.

23. Jurčević, B. \& Mihelja Žaja, M. (2013). Banks and insurance companies efficiency indicators in the period of financial crisis: The case of the Republic of Croatia. Ekonomska istraživanja, 26(1), 203-224. https://doi.org/10.1080/1331677X.2013.11517598

24. Karbhari, Y., Muye, I., Hassan, A. F. S. \& Elnahass, M. (2018). Governance mechanisms and efficiency: Evidence from an alternative insurance (Takaful) market. Journal of International Financial Markets, Institutions and Money, 56, 71-92. https://doi.org/10.1016/j.intfin.2018.02.017

25. Kozak, S. (2010). Consolidation and efficiency of the non-life insurance sector in Poland. Electronic Journal of Polish Agricultural Universities, 13(1).

26. Kozak, S. (2018). Efficiency of non-life insurance companies and its determinants. Acta Scientiarum Polonorum. Oeconomia, 17(4), 87-95. https://doi.org/10.22630/ASPE.2018.17.4.55

27. Lukić, R., Sokić, M. \& Vojteski Kljenak, D. (2018). Analysis of insurance companies' efficiency in the Republic of Serbia. Economic and Environmental Studies, 18(1), 249-264.

https://doi.org/10.25167/ees.2018.45.14

28. Magyar Nemzeti Bank (MNB) (2020). Golden Book.

https://www.mnb.hu/en/supervision/time-series/golden-books

29. Mandić, K., Delibašić, B., Knežević, A. \& Benković, S. (2017). Analysis of the efficiency of insurance companies in Serbia using the fuzzy AHP and TOPSIS methods. Ekonomska istraživanja, 30(1), 550-565. https://doi.org/10.1080/1331677X.2017.1305786

30. Micajkova, V. (2015). Efficiency of Macedonian insurance companies: A DEA approach. Journal of Investment and Management, 4(2), 61-67. https://doi.org/10.11648/j.jim.20150402.11

31. Medved, D. \& Kavčič, S. (2012). An empirical study of efficiency in Croatia and Slovenia insurance markets. Ekonomska istraživanja, 25(1), 87-98. https://doi.org/10.1080/1331677X.2012.11517496

32. Polish Chamber of Insurance (PIU) (2020). Statistics. https://piu.org.pl/en/annual-piu-report

33. Škrinjarić, T. (2017). Analiza relativne efikasnosti industrije osiguranja europskih zemalja korištenjem analize omeđivanja podataka. Ekonomski pregled, 67(1), 3-26. https://doi.org/10.32910/ep.72.1.1

34. Wang, C. N., Nguyen, N. T. \& Tran, T. T. (2015). Integrated DEA Models and Grey System Theory to Evaluate Past-to-Future Performance: A Case of Indian Electricity Industry. The Scientific World Journal, 2015. https://doi.org/10.1155/2015/638710

35. Weiss, M. A. (1991). International P/L insurance output, input, and productivity comparisons. The Geneva Papers on Risk and Insurance Theory, 16(2), 179-200. https://doi.org/10.1007/BF02386306

36. Weiss, M. A. \& Choi, B. P. (2008). State regulation and the structure, conduct, efficiency and performance of US auto insurers. Journal of Banking and Finance, 32(1), 134-156.

https://doi.org/10.1016/j.jbankfin.2007.09.010 